\title{
Establishment of Legal Safeguard Mechanism for Heilongjiang's Economic Trade with Russia under the Framework of Longjiang Silk Road Economic Belt
}

\author{
Hui Xie \\ Heihe University \\ Heihe, China
}

\begin{abstract}
To promote the construction of "Longjiang Silk Road Economic Road" and accelerate the establishment of risk control and legal Safeguard mechanism for Sino-Russian economic trade cooperation will play a significant role in standardizing and legalizing the Sino-Russian economic trade relations. Based on Heilongjiang's trade to Russia under the Longjiang Economic Silk Road Economic Belt, this article analyzes the influences of legal changes of Russia's entry to the WTO to the economy and trade in Heilongjiang Province, and builds a legal Safeguard mechanism for the economic trade cooperation between Heilongjiang and Russia, which will help understand Russian laws, regulations and trade policies, deal with legal risks and solve disputes in trades through negotiation.
\end{abstract}

Keywords-Longjiang Silk Road Economic Belt; economic trade cooperation with Russia; legal safeguard

\section{INTRODUCTION}

To integrate the Longjiang Silk Road Economic Belt to the Belt and Road Initiatives is a significant measure to achieve a new round of opening up and economic and social transformation under the new normal economy in Heilongjiang Province. To establish a legal Safeguard mechanism for economic trade cooperation with Russia will help conduct risk controls over the trade with Russia and solve disputes in trade, which has significant practical significance in strengthening Sino-Russian economic relations.

Fund Project: (1) Staged results (16FXB05)of Studies on Heilongjiang's Legal Safeguard Mechanism for economic trade Cooperation with Russia under the Longjiang Silk Road Economic Belt framework, General Project of Heilongiang Philosophy Social Sciences Studies in 2016. (2) Staged results (17YDZKBYY03) of Studies on Legal Safeguard Mechanism for economic trade Cooperation with Russia, a Key Project of Countermeasures for Think Tank Application of Russia by Heihe University in 2016.

\section{TENDENCY OF HEILONGJIANG'S TRADE TO RUSSIA} UNDER THE LONGJIANG SILK ROAD ECONOMIC BELT

\section{A. Significance of Longjiang Silk Road Economic Belt Construction}

In 2014, based on the great strategy advocated by President Xi Jinping, Heilongjiang Provincial Party Committee raised an overall layout of Heilongjiang Silk Road Economic Belt. One year later, the "Promote to Jointly Build Silk Road Economic Belt and Vision and Actions for the 21st Century Maritime Silk Road" was released, and the Longijang Silk Road Economic Belt was formally included in the national strategy of "the Belt and Road Initiatives China-Mongolia-Russian Economic Corridor". Building the Longijang Silk Road Economic Belt is to fully make use of the geo-advantages of Heilongjiang adjacent to Russia and solidify its position as bridge tower and hub to Russia, as a logistic belt for international trade and industrial belt for factor clusters, the Longijang Silk Road Economic Belt not only has strategic significance for countries along the belt but also drives the joint economic development between China and Russia.

\section{B. Status Quo of Heilongjiang's Economic Trade with Russia}

1) Trades with Russia: The province's import \& export with Russia reached 10.85 billion dollars in 2015 , occupying $51.7 \%$ and $15.9 \%$ of the province's import \& export and the country with Russia respectively. Of which, its export to Russia totaled 2.35 billion dollars, its import from Russia totaled 8.49 billion dollars, occupying $65.6 \%$ and $25.5 \%$ of the province's import and the country' import from Russia respectively. The trades with Russia are mainly general trade and border small-volume trade, occupying $57.5 \%$ and $32.1 \%$ of total import \& export with Russia respectively. In trades with Russia, state-owned enterprises are predominate, private ones are active, the total import \& export with Russia by state-owned enterprises occupy $61.1 \%$, the total import \& export with Russia by private 
ones occupy $38.1 \%$. The export of garment, shoes, textiles, mechanical and electronic products, agricultural and side products to Russia occupies a higher proportion, and the export of garment, shoes and textile products occupy $48.3 \%$ of the province's total export to Russia, the export of mechanical and electronic products, new $\&$ hi-tech products, agricultural and side products occupy $21.3 \%, 1.2 \%$ and $20.2 \%$ of the province's total export to Russia respectively. Top ten commodities imported from Russia mainly are rude oil, logs, converted timbers, fertilizer, iron ore and relevant concentrates, grains, paper pulp, coal, finished oil, synthetic rubber and so on, occupying $95.3 \%$ of total import from Russia. For the first time, the borders' trade is included in statistics of customs data, which adds new drive for the province's trade with Russia. The cross-border E-commerce with Russia develops faster with great potentials, in 2015, the province's international postal parcels to Russia totaled 14.4534 pieces, with goods of 3180 tons transported. There are 8 cities with import \& export with Russia over 100 million dollars, which form the major part for trades wit Russia, especially Heihe, Suifenhe, Dongning, Mohe, Tongjiang, Fuyuan, Mishan and Raohe port have obvious roles as backbones. ${ }^{1}$

2) Investment in and cooperation with Russia: By the end of 2015, there were 505 enterprises investing in Russia, with investment amount of 9.92 billion dollars, of which, Chinese investment reached 7.603 billion dollars, 2.59 billion dollars of which had been invested. In 2015, 99 enterprises had been filed for investment in Russia, increased by $75 \%$ year by year, and the investment totaled 4.179 billion yuan, increased by $182 \%$ year by year, occupying $60.56 \%$ of filed investment in the province; the business volume of project contracting in Russia totaled 235 million dollars, occupying $9.34 \%$ of the province, increased by $48.5 \%$ year by year. Heilongjiang's investment in Russia is mainly focused on energy, forestry, agriculture, processing industry and park construction, and the project contracting and labor cooperation in Russia are centered on forest deforestation, agricultural planting and construction engineering. Investment cooperation projects are mainly established in riverside areas, Khabarovsk area, Judaic Autonomous Oblast, Amur Oblast and Zabaikalsky Krai ${ }^{2}$

\section{Analysis of Heilongjiang's Economic Trade Development Tendency with Russia}

Specifically, Heilongjiang's economic trade development trend with Russia is optimistic, and the trade cooperation size is increased as well. However, there are some malpractice and defects which are exposed in the process of economy and trade.

\footnotetext{
${ }^{1}$ Refer to http://www.hlj.gov.cn/ztzl/system/2016/02/17/010761364.shtml, Introduction to Heilongjiang's economic trade Cooperation with Russia, Heilongjiang People's Government

2 Ditto.
}

Supported by economic trade policies of the two countries, relying the adjacent geographic position, strength in resources, Heilongjiang has been deepening the economic trade relations with Russia: First, Heilongjiang has stabilized the economic trade with Russia, which is enlarging increasingly; Second, the bilateral trade structure between Heilongjiang and Russia is complementary; Third, Heilongjiang has improved its economic trade cooperation with Russia; Fourth, Heilongjiang has improved its investment environment in Russia; Fifth, Heilongjiang has more wide fields for economic trade cooperation with Russia.

1) Deficiency in the economic trade development: Seen as a whole, the problems and malpractice cannot be underestimated during the Sino-Russian economic trade development, so do the economy and trade between Heilongjiang and Russia. First, the bilateral trade between China and Russia is unbalanced, after 2007, China's trade surplus with Russia has been expanding. Second, the proportion of trade between China and Russia needs to be increased among the two countries, and Russia has lowered its position among China's trading partners. III. The commodities import \& export are simple in structure for China and Russia, which fail to fit in with current economic structure and development level of the two countries. IV. On regulating the trade systems, both China and Russia need more policy support and perfection. Fifth, on perfecting financial service systems, China and Russia still need to make more efforts.

\section{INFLUENCE OF LEGAL CHANGES BY RUSSIA'S ENTRY TO THE WTO TO THE BORDER TRADE OF HEILONGJIANG}

\section{A. Legal Reform in Russia after Its Entry to the WTO}

In 2011, Russia succeeded in its entry to the WTO, becoming the 156th member countries in the WTO and ending the 19 year-long race for the WTO. For Russia, changed from the former the Soviet Union, consists of 83 states, whose legal systems and judicial systems are extremely complicated. In order to meet requirements of the WTO, Russia had removed and modified lots of domestic laws and regulations before the entry. Relevant data show, from 1994 to now, Russia has more than 3500 local laws and regulations modified, correcting over 1000 department rules, modifying hundreds of federal laws, which show that Russia had conducted strong and wide "surgery" on its laws and how firm its decision to enter the WTO.

The renewed and foreign trade related laws and regulations mainly include: Law of Russian Federation on Foreign Investment, Law of Russian Federation on Product Prorata Agreement, New Customs Code of Russian Federation, Tariff Rule of Russian Federation Modification and Supplement, Law of Russian Federation on Foreign Exchange Adjustment and Control, Laws of Russian Federation on Foreign Trades Adjustment, Law of Russian Federation on Special Protection of Goods Import, AntiDumping and Anti-subsidy Measures, Law of Russian Federation on Technical Management, Law of Russian 
Federation on Special Economic Zones, New Law of Russian Federation on Communications, New Law of Russian Federation on Insurance Operation, New Law of Russian Federation on Banks, New Law of Russian Federation on Protecting Rights and Legal Benefits of Investors in Securities Market, Law of Russian Federation on Special Economic Zone in Kaliningrad, Law of Russian Federation on Special Economic Zone in Magadan and so on.

\section{B. Reflection of Trade Protection in Legal Changes}

In accordance with the foreign policies of Russian Federation approved by Russian president on Feb 12, 2013, main tasks of Russian Federation in the international economic relations are to protect the equal position of Russia in the current world economic relations, so as to minimize the risks arising out of the process of world economic integration, entry to the WTO and the OCED. Premises to achieve the tasks are: 1 . Take measures under laws to protect private benefits and fight against other country's foreign policies that restrict the rights of Russian Federation and the development of Russian enterprises. 2. Protect the benefits that Russia should have during the development and functionalizing of world economy. 3. Create favorable policy conditions so that Russia can conduct multiple operation in world markets through adding export kinds and expanding foreign investment areas. 4. Provide state support to Russian enterprises which develop new markets and expand new markets, fighting against investors and exporters that discriminate Russian investors. 5. Promote the modern and diverse development of Russian economy, rely on internationally advanced technologies, processes and operation management modes, launch operations and attract foreign investment to increase the proportion of knowledge intensive and innovative industries as well as other prior industries in the social and economic system. 3

\section{Influences of Russian Changes on the Border Trade on Heilongjiang}

Russia's entry to the WTO brings new opportunities and challenges for the border trade between China and Russia, which is seen as a whole doing good more than harm.

1) Positive influence: New laws and policies in Russia have created better conditions to attract foreign investment, which will greatly promote the economic development in the country. 1. Help to improve the environment for trades and investment. After its entry to the WTO, Russia has it transparency increased in trade policy and judicial and administrative procedures, and the safety and stability of economic trade exchanges will be further improved. 2. Help to regulate the border trade. After Russia's entry to the WTO, a series of problems such as arbitration, trade settlement, clearance procedures, commodity inspection and so on will be settled as per standards of the WTO, and the

\footnotetext{
${ }^{3}$ Legal Risks Prevention Guidelines of One Belt One Way Countries (Russia), Beijing, Economic Science Press, 2016.4.
}

"grey clearance" existing for a long time in Heilongjiang will be settled. 3. Help to enlarge the border trade size: After Russia's entry to the WTO, two countries will reduce tariffs for import \& export, opening markets, which will do good to expand imports of resource-based commodities from Russia. 4. Help to improve the financial service levels between the two countries. After Russia's entry to the WTO, the bank settlement between China and Russia will be done as per standards of the WTO, with non-standard operation greatly reduced.

2) Negative influence: After Russia's entry to the WTO, the negative influences of border trade of Heilongjiang are mainly reflected from the following: 1 . private trade will in declination as a whole. And standard companies will replace private trade with international trade, and the industrial sales chain "individual $\rightarrow$ manufacturers purchase goods $\rightarrow$ export to Russia $\rightarrow$ sell goods at Russian markets $\rightarrow$ remit goods income to China through settlement" that has existed for a long time will break. 2. Hotter market competition: After Russia's entry to the WTO, it has t compete with all rivals around the world. Medium and small private enterprises are difficult to cooperate with Russian ones for development of technology, energy and natural resources, besides; most products exported belong to labor intensive ones, with lower competitiveness. 3. Higher risks of loss due to knowing little of the WTO standards: There exist nonstandard operation between Sino-Russian trades in trade mode, settlement, dispute settlement, clearance, goods inspection and so on, with the successful entry to the WTO, Russia will improve relevant standards, which are changes for the border trade of Heilongjiang.

\section{LEGAL SAFEGUARD MECHANISM FOR ECONOMY AND TRADE WITH RUSSIA}

\section{A. Strengthen Exchanges and Cooperation between Judicial Circles of the Two Countries}

First, it needs to strengthen the communications and cooperation between judicial departments of the two countries. The Sino-Russian Good-Neighborly Treaty of Friendship and Cooperation approved by heads of the two countries has confirmed specific goals and tasks for judicial cooperation of the two countries. In future, under the Communications and Cooperation Agreement by and between Ministry of Justice of the PRC and Ministry of Justice of Russian Federation and executive plans, the two countries should strengthen connections in cooperation mechanism, top leader communications, judicial aids and so on. Second, legal exchanges and cooperation shall be strengthened by and between China and Russia, for Russia is a federal country, all member states under it has special laws of their own, Heilongjiang authorities shall understand the laws, policies and risks related to the regions for cooperation so as to protect the max rights of Chinese investors. Third, lawyers and academic circles between the two countries shall strengthen communications, promote the understanding and learn each other, and Chinese side shall 
actively absorb the essence and excellence of laws and regulations related to the foreign trade in Russia to make up the deficiency of the legislation in China and remove the legal blindness for the bilateral trades between the two countries.

\section{B. Strengthen the Preventive Consciousness against Legal Risks in Trades with Russia}

The lack of legal awareness of border traders is one of the root reasons for disputes arising out the border trade, accordingly, we should strengthen the publicity of judicial aids treaty and foreign trade laws, improve the legal awareness of border traders, clearly understanding the legal risks of economic trade cooperation so as to regulate transaction behaviors and lower disputes. On the one hand, actively hold discussions with the CPPCC, enterprise chambers and so on, deeply study and compile Guide for Legal Service of Civil Lawsuits with Russia, try best to create convenient conditions for the public understand and learn the law systems of civil lawsuits in Russia and seeking for legal remedies. On the other hand, adopt divers forms such as analyzing typical cases, legal consultancy, targeted law lectures and so on and publicize practical law knowledge simple and easy to understand, educate and guide market participants to raise abilities of risk prevention and crisis prevention. In the meantime, make full use of advantages of media in publicity, conduct topic lectures about understanding and application of Sino-Russia Mutual Assistance Treaty and foreign economic laws through radio, TV and Internet, making more and more traders gradually learn to protect rights and benefits of their own through laws during the foreign operation.

\section{Perfect Legal Safeguard Mechanism for Risk Evaluation and Foreign Rights Protection}

For Russian laws are unstable, especially the laws of Russian Federation are separated from the laws of divers areas, so it needs establish and perfect the safeguard mechanism for risk estimation and foreign rights protection. First, Heilongjiang authorities should strengthen instruction to investors; timely renew the law changes in Russia so as to reduce the economic loss of investors due to knowing little of Russian laws. Second, for projects that cooperation has been established, just trace the project progress, timely get difficulties faced in trades with Russia and provide assistance when necessary. Third, we should establish investment risk evaluation system for key industries and areas for investment from China; instruct enterprises to develop toward the industries and areas with favorable investment environment and great potentials so as to lower the legal risks for investment in Russia. Finally, it is recommended that authorities and legal sectors should set up governmental and non-governmental legal service and agencies so as to provide enterprises and individuals in Russia with law consultancy, commercial consultancy, tourist guide, introduce commercial projects, help recruit employees and solve difficulties for companies and individuals doing business in Russia.

\section{Intensify the Cultivation of Compound Talents Relative to Russia Laws}

In order to expand foreign law business, it needs to speed up the cultivation of law+ Russian compound talents. First, educational departments and colleges shall strengthen the cultivation of talents relative to Russian and Russian laws, intensify the communication and cooperation between educational departments of the two countries, establish a valid mechanism for talent exchanges, provide students with background of language and laws with more chances for international study and reserve talents for investment in Russia. Increase investments to researches on Russian law and attract more scholars to deeply research Russian laws so as to avoid legal risks in trades with Russia. Second, legal circles shall cultivate talents with Russian background and knowing Russian laws, establish teams to promote the economic trade cooperation with Russia, conduct deep researches on Russian legal systems, make full efforts to handle investment projects and solve the lack of legal strength during the economic trade cooperation with Russia. Second, raise the practice of Russian, speaking strictly students of law major shall well master Russian and own abilities of communications, able to translate the law knowledge that they've learned to clarify it clearly, improve the skills in Russian expression, change the strange phenomena that students majoring in law are afraid of speaking so as to raise the abilities and levels of foreign law business.

\section{CONCLUSION}

"Longjiang Silk Road Belt" is a regional plate of the Belt and Road Initiatives strategy, Heilongjiang makes full use of the state strategy and Sino-Russian friendly cooperation to promote the economic upgrading. The connection and implementation of "Longjiang Silk Road Belt" Sino-Russian cooperation projects must follow basic principles of the WTO and international economic operation, and the establishment of legal safeguard mechanism for Heilongjiang's economy and trading with Russia will help strengthen the risk prevention and control and legal safeguard mechanism for the Sino-Russian cooperation, and finally eliminate trade barriers, regulate trade orders, deal with business disputes, control investment risks, exert the supervisory mechanism and play a solid foundation in the new performance of achieving the economic revitalization in a new round of opening up.

\section{REFERENCES}

[1] Zhang Xiaolin, Carry out the Belt and Road Initiatives and Promote the Longjiang Silk Road Economic Belt Construction [J].Study \& Exploration, 2015(1)

[2] Zheng Shipeng, Building Cultural Exchange Mechanism In the Construction of the Belt and Road Initiatives [J].Academic Exchanges, 2015(2).

[3] Zhao Yu, Discussion on Deepening economic trade Cooperation Between Northeast China and Russia [J]. Heilongjiang Social Sciences,2014(6). 
[4] Guo Wei, Influences of Legal Reforms During Russia's Entry to the WTO on Legal Environment for Foreign Investment [D] Beijing Foreign Studies University, 2015. 